\title{
A Micromethod for the Stereospecific Determination of Triglyceride Structure ${ }^{1}$
}

\section{William E. M. Lands, Ronald A. Pieringer, Sister P. M. Slakey ${ }^{2}$ and Albrecht Zschocke, ${ }^{3}$}

The University of Michigan, Ann Arbor, Michigan, and Temple University, School of Medicine, Philadelphia, Pennsylvania

\section{ABSTRACT}

Triglyceride lipase and diglyceride kinase can be used in a sensitive stereospecific analysis of the separate fatty acid compositions at the 1,2 and 3 positions of a triglyceride.

Diglyceride kinase from Wseherichior coli selectively catalyzes the phosphorylation of 1,2-diglycerides but not the 2,3-diglycerides.

The composition of the 3-position in rat liver triglyeerides is clearly different from that at the 1-position.

\section{INTRODUCTION}

A NALYSES ON HUNDREDS of triglyceride mixtures led Hilditch to propose rules of "even distribution" and "random distribution" for vegetable and animal fats (2). These rules were designed to indicate the manner in which the various acids were combined to form the triglyceride mixtures. A considerable modification of these rules was needed after pancreatic lipase was used to produce 2-monoglycerides from triglycerides (3). The fatty acids were clearly recognized to be distributed between the primary and secondary positions in a nonrandom manner. This new reagent showed no preference for one of the primary ester groups over the other, but hydrolyzed both at the same rate (4). In interpreting the data obtained from studies using pancreatic lipase, Vander Wal (5) and Coleman and Fulton (6) assumed that fatty acids are distributed in the same proportion in the 1- and 3-positions. They suggested that the relative amounts of triglyceride species in a naturally occurring mixture could be predicted assuming a 1,3-random -2-random distribution of the fatty acids. Recently Vander Wal (7) properly indicated that the calculated percentage compositions of the triglycerides in a mixture are barely affected by large deviations from the 1,3-random distribution. Thus, the currently available data on the pexcentages of the individual triglycerides in a mixture (e.g., 8) neither support nor deny the 1,3-random hypothesis.

The discussions of stereochemistry by Schwartz and Carter (9) and Hirsehmann (10) have emphasized the fact that regardless of \footnotetext{
(1).

'A preliminary report of this work has been presented

2 National Science Foundation Graduate Fellow.

${ }^{3}$ Present address: Badische Anilin and Soda Fabrik, Ludwigshofen, Germany.
}

fatty acid substituents, the 1 - and 3-positions of glycerol are not interchangeable. This concept led us to attempt a stereospecific analysis of the separate acid compositions at the 1,2 and 3 positions of a triglyceride. We felt that the new method needed to be sufficiently sensitive to characterize the small amounts of triglycerides generally obtained in metabolic studies. The method developed uses the diglyceride kinase of Escherichia coli to selectively phosphorylate the 1,2-diglycerides from the mixture of diglycerides formed by pancreatic lipase. Thus a comparison of the fatty acids in the intact triglyceride, the monoglyceride produced by lipase, and the phosphatidate formed in the kinase reaction indicates the acids esterified at each position of the triglyceride. Brockerhoff has described a different procedure to achieve the same goal (11). The present paper presents evidence that diglyceride kinase is a suitable reagent for use in a sensitive stereospecific determination of triglyeeride structure.

\section{MATERIALS AND METHODS}

\section{Stereoisomers of Dipalmitin}

1-O-Benzylglycerol and 3-0-benzylglycerol were prepared as deseribed by Lands and Zschocke (12). The benzylglycerols were acylated with palmitic anhydride essentially as described by Mattson et al. (13). Benzylglycerol (10 mmoles) and palmitic anhydride (22 mmoles) were dissolved in dry chloroform and $0.055 \mathrm{ml}(0.66$ mmoles $)$ of $70 \% \mathrm{HClO}_{4}$ were added. The reaction was stirred at room temperature for $1.5 \mathrm{hr}$, stopped by the addition of water, and shaken with ether. The ether layer was washed three times with water, then washed with $0.1 \mathrm{~N} \mathrm{NaOH}$ in $50 \%$ ethanol until the washings were basic. The ether solution was washed once with $50 \%$ ethanol, dried over
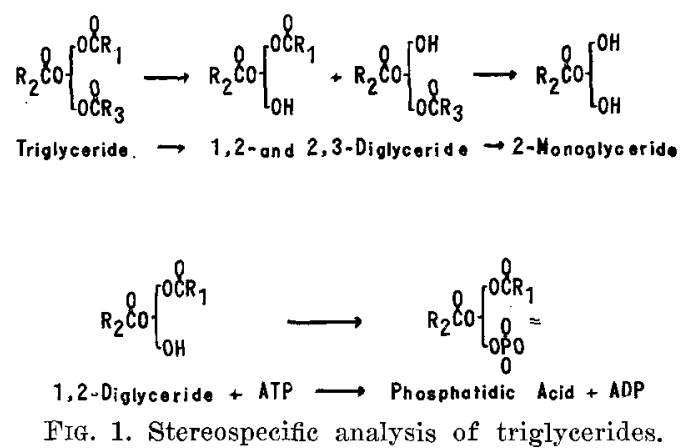
sodium sulfate, and then evaporated. The product was recrystallized from acetone to give $4.6 \mathrm{~g}$ of 1,2-dipalmitoyl-3-benzylglyeerol, $\mathrm{mp}$ $34-36 \mathrm{C}, a_{1}+5.5^{\circ}$ in chloroform. The yield of 2,3-dipalmitoyl-1-benzylglycerol was $4.8 \mathrm{~g}, \mathrm{mp}$ $35-37 \mathrm{C}, \alpha_{\mathrm{D}}-6.25^{\circ}$ in chloroform.

Hydrogenolysis of the benzyldipalmitoylglycerol to dipalmitin was carried out in acetic acid using $\mathrm{Pd} / \mathrm{C}$ catalyst. The sample was shaken at room temperature under 16 psi of hydrogen for $7 \mathrm{hr}$. The insolnble dipalmitin was taken up in ether and the catalyst removed by filtration. The ether was evaporated and the product recrystallized once from ether. The amount of $0.11 \mathrm{~g}$ of dipalmitin mp 57-59C was obtained from $1.5 \mathrm{~g}$ benzyldipalmitoylglycerol. The $a_{\mathrm{p}}$ in chloroform for the 1,2-dipalmitin was $-2.15^{\circ}$, and for the 2,3-dipalmitin, $+2.6^{\circ}$.

\section{Preparation of Enzymes}

Triglyceride Lipase. Steapsin (Nutritional Biochemicals Co.) was extracted with $10 \%$ saturated $\mathrm{NaCl}$ (200 mg steapsin per ml), adjusted to $\mathrm{pH}$ 7.0. Diisopropyl fluorophosphate $\left(5 \times 10^{-5} \mathrm{M}\right)$ was added to inhibit proteolytic enzymes. The lipase was measured by a microadaptation of the procedure of Desnuelle (14). One unit of activity is one microequivalent of ester hydrolyzed $/ \mathrm{ml} / \mathrm{min}$. The enzyme was precipitated with $60 \%$ saturated $\left(\mathrm{NH}_{4}\right)_{2} \mathrm{SO}_{4}$, dissolved in $0.05 \mathrm{M}$ sodium acetate $-0.005 \mathrm{M}$ calcium chloride, $\mathrm{pH} 5.3$ and dialyzed against the same buffer. The solution was then chromatographed on Sephadex G-200. The most active fractions were combined and the enzyme was precipitated as above and rechromatographed. The pooled active fractions from the second chromatography (specific activity, 270 units $/ \mathrm{mg}$; protein concentration, $0.1 \mathrm{mg}$ / $\mathrm{ml}$ ) were used for the routine triglyceride analyses deseribed below.

Diglyceride Kinase. Diglyceride kinase was prepared as described by Pieringer and Kunnes (15). It was stored after heat treatment in cysteine phosphate buffer at $-10 \mathrm{C}$. No loss of aetivity was observed for 1-2 months.

\section{Chromatographic Methods}

Thin-layer chromatography was done on plates coated $0.25 \mathrm{~mm}$ thick with Mallinckrodt reagent grade silicic acid, 200 mesh. The plates were dried in air for $1 \mathrm{hr}$ after spreading, activated for $1 \mathrm{hr}$ at $105 \mathrm{C}$, and stored in air until use within one or two days.

Gas chromatography of the methyl esters was done using a Barber-Colman instrument equipped with a hydrogen flame detector and a $1 / 4$ in. $\times 8 \mathrm{ft}$ column packed with $10 \%$ ethylene glycol suceinate on Gas-Chrom P. The column temperature was $195 \mathrm{C}$.

\section{Stereospecificity of Diglyceride Kinase}

The speeificity of the diglyeeride kinase of Escherichia coli for either 1,2- or 2,3diglycerides was determined by measuring the amount of radioactivity incorporated from ${ }^{32} \mathrm{P}$ ATP (labeled in the $\gamma$-phosphate) into phosphatidic acid in the presence of either stereoisomer of dipalmitin under conditions described by Pieringer and Kunnes (15).

\section{Triglyceride Analysis}

The triglyceride ( 2 to $5 \mathrm{mg}$ ), dissolved in ether or hexane, was pipetted into a $13 \times 100$ $\mathrm{mm}$ test tube and the solvent was removed with a stream of nitrogen. The amounts of $0.15 \mathrm{ml}$ of $1.0 \mathrm{M} \mathrm{NaCl}, 0.10 \mathrm{ml}$ of $1.0 \mathrm{M}$ tris $\mathrm{HCl}(\mathrm{pH}$ $8.05)$ and $0.05 \mathrm{ml}$ of lipase $(2.7$ units $/ \mathrm{ml})$ were added. The reaction was mixed on a Vortex mixer at room temperature for approximately $3 \mathrm{~min}$, then stopped by the addition of $0.20 \mathrm{~mL}$ of $1 \mathrm{~N} \mathrm{HCl}$. The lipids were extracted first with $1.3 \mathrm{ml}$ of $\mathrm{CHCl}_{3}: \mathrm{MeOH}$, $2: 1(\mathrm{v} / \mathrm{v})$ and then with $0.80 \mathrm{ml}$ of $\mathrm{CHCl}_{3}$. The combined chloroform extracts were evaporated and the lipid taken up in $0.10-0.20 \mathrm{ml}$ of $\mathrm{CHCl}_{3}: \mathrm{MeOH}, 2: 1$ and put on a TLC plate. The plate was developed with $60 \%$ diethyl ether in petroleum ether $(30-60 \mathrm{C})$ to about 4 $\mathrm{cm}$ from the origin, dried in air for at least $15 \mathrm{~min}$, then developed to the top in $12 \%$ diethyl ether in petroleum ether. The bands were visualized by spraying with $1 \% \mathrm{I}_{2}$ in methanol. Dichlorofluorescein should not be used to visualize the bands because it is carried along with the diglyceride and inhibits the kinase. The diglyceride and monoglyceride bands were scraped into small columns and the lipid eluted with $10 \mathrm{ml}$ of $5 \%$ methanol in ether.

The solvent was evaporated from the diglyeeride, and the following reagents were added: $10 \mu \mathrm{l}$ of $200 \mathrm{mg} / \mathrm{mI}$ of mixed bile salts (Difeo Laboratory, Detroit, Mich.) ; $0.10 \mathrm{ml}$ of $0.05 \mathrm{MI}$ ATP; $0.05 \mathrm{ml}$ of $1.0 \mathrm{M} \mathrm{MgCl} ; 0.05 \mathrm{ml}$ of 0.50 M sodium phosphate buffer, $\mathrm{pH} 7.95 ; 0.10 \mathrm{ml}$ of crude diglyceride kinase, ea $8 \mathrm{mg} / \mathrm{ml}$. (The final $\mathrm{pH}$ of the reaction mixture was 7.0 ). The reaction was incubated with constant shaking at $37 \mathrm{C}$. At the end of one hour $0.20 \mathrm{ml} 1 \mathrm{~N}$ $\mathrm{HCI}$ was added and the lipids extracted with $2.0 \mathrm{ml}$ of $\mathrm{CHCl}_{3}: \mathrm{MeOH}, 2: 1$, followed by 1.3 $\mathrm{ml}$ of $\mathrm{CHCl}_{3}$. One drop of triethylamine was added to the combined chloroform extracts, the solvent evaporated, and the residue taken up in $0.10-0.20 \mathrm{ml} \mathrm{CHCl}{ }_{3}: \mathrm{MeOH}, 2: 1$, and ap- 
plied to a TLC plate. The plate was developed to the top with $80 \%$ diethyl ether in petroleum ether $(30-60 \mathrm{C})$, allowed to dry at least $15 \mathrm{~min}$, then developed to a distance of $12 \mathrm{~cm}$ with chloroform :ethanol :formic acid, $100: 10: 5$. The bands were visualized with dichlorofluorescein. The phosphatidic acid band was scraped and eluted with $10 \%$ methanol in ethanol. Two components of the bile salt mixture run just above and just below the phosphatidic acid; however, contamination from these bands does not interfere with the analysis.

A known amount (ca 150 m $\mu$ moles) of methyl pentadecanoate was added as an internal standard to each sample. The solvent was evaporated and $2 \mathrm{ml}$ of $0.5 \mathrm{~N}$ sodium methoxide in methanol added. The reaction was stopped after $10 \mathrm{~min}$ with $0.2 \mathrm{ml}$ of $6 \mathrm{~N} \mathrm{HCl} .5 \mathrm{ml}$ of petroleum ether and $5 \mathrm{ml}$ of water were added and mixed on the Vortex mixer. The petroleum ether layer was dried over $\mathrm{Na}_{2} \mathrm{SO}_{4}: \mathrm{NaHCO}_{3}$, $2: 1(\mathrm{w} / \mathrm{w})$ for at least $10 \mathrm{~min}$, then decanted from the drying agent. The solvent was removed under a stream of nitrogen, with gentle warming, and the methyl esters were taken up in 20-30 $\mu \mathrm{l}$ of $\mathrm{CS}_{2}$. Portions of this solution $(1-4 \mu 1)$ were used for injection into the gas chromatograph.

The amount of each ester present was ealculated from the product of the peak height and the retention time, measured in centimeters from the point of injection. The latter was directly proportional to the peak width at half-height, and can be measured more precisely. This product, $P$, was used to calculate the fatty acid content as shown below.

m $\mu$ moles of acid $=$

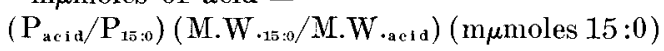

The mole per cent compositions of acids in the triglycerides, the monoglycerides, and the phosphatidic acids were caleulated and the distribution of the acids was calculated as shown in the sample calculation in Table III.

\section{RESULTS}

To determine that the hydrolysis of the triglycerides was independent of the fatty acid composition under the conditions used, the unreacted triglycerides and products formed at different extents of reaction were recovered and analyzed. The results in Table I show that throughout the course of the reaction, the fatty acid compositions were constant within the limits of experimental error. The triglycerides were almost completely hydrolyzed by the lipase by the time that $58 \%$ of the total esters was cleaved.

A similar check was made of the fatty acid composition of the product and unreacted substrate during the phosphorylation of mixed 1,2-diglycerides with diglyceride kinase. For this experiment a mixture of 1,2-diglycerides was prepared from the lecithins of pig liver using phospholipase $\mathrm{C}$ from Clostridium welchii as described by Lands and Hart (16). This diglyceride mixture, which contained a variety of commonly encountered types, was incubated with diglyceride kinase as described above. The results in Table II show that the relative amounts of the component acids in the substrate and product are essentially constant throughout the course of the reaction. The small differences in $20: 4 \omega 6$ and $22: 6 \omega 3$ could indicate a difference in phosphorylation rates, but when $45 \%$ of the diglyceride was reacted, the phosphatidate composition was

TABLE I

Composition of Lipase Hydrolysis Products Composition (moles \%)

\begin{tabular}{|c|c|c|c|c|c|c|}
\hline Product $^{\mathbf{a}}$ & Acid & $0 \mathrm{~min}$ & $3 \mathrm{~min}$ & $6 \mathrm{~min}$ & $12 \mathrm{~min}$ & Average \\
\hline $\mathbf{T G}$ & $\begin{array}{l}14: 0 \\
16: 0 \\
16: 1 \\
18: 0 \\
18: 1 \\
18: 2\end{array}$ & $\begin{array}{c}3.1 \\
25 \\
6.9 \\
4.5 \\
27 \\
33\end{array}$ & $\begin{array}{c}2.4 \\
27 \\
5.3 \\
4.9 \\
27 \\
33\end{array}$ & $\begin{array}{c}2.2 \\
29 \\
5.8 \\
4.8 \\
29 \\
30\end{array}$ & $\begin{array}{l}2.4 \\
29 \\
6.1 \\
5.3 \\
25 \\
31\end{array}$ & $\begin{array}{c}2.5 \\
27 \\
6.0 \\
4.9 \\
27 \\
32\end{array}$ \\
\hline $\mathrm{DG}$ & $\begin{array}{l}14: 0 \\
16: 0 \\
16: 1 \\
18: 0 \\
18: 1 \\
18: 2\end{array}$ & & $\begin{array}{c}2.4 \\
29 \\
4.7 \\
4.7 \\
26 \\
33\end{array}$ & $\begin{array}{c}2.3 \\
26 \\
5.2 \\
4.4 \\
27 \\
35\end{array}$ & $\begin{array}{c}2.1 \\
26 \\
6.3 \\
4.1 \\
26 \\
34\end{array}$ & $\begin{array}{c}2.3 \\
27 \\
5.4 \\
4.4 \\
27 \\
34\end{array}$ \\
\hline Total & $\begin{array}{c}14: 0 \\
16: 0 \\
16: 1 \\
18: 0 \\
18: 1 \\
18: 2 \\
\text { olyzed }\end{array}$ & & $\begin{array}{l}2.4 \\
11 \\
5.7 \\
30 \\
51 \\
27 \%\end{array}$ & $\begin{array}{l}1.1 \\
8.6 \\
5.7 \\
0.9 \\
29 \\
54 \\
42 \%\end{array}$ & $\begin{array}{c}1.3 \\
10 \\
6.6 \\
1.2 \\
30 \\
50 \\
58 \%\end{array}$ & $\begin{array}{c}1.6 \\
10 \\
6.3 \\
0.7 \\
30 \\
51\end{array}$ \\
\hline
\end{tabular}

a TG, triglycerides; $\mathrm{DG}$, diglycerides; $M G$, monoglycerides.

LiPIDS, Vol. 1, No. 6 
TABLE II

Diglyceride Kinase:

Composition of Substrate and Producta

\begin{tabular}{|c|c|c|c|c|c|c|c|c|c|}
\hline \multirow[b]{2}{*}{ Acid } & \multirow{2}{*}{$\begin{array}{c}0 \text { min } \\
\mathrm{DG}\end{array}$} & \multicolumn{2}{|c|}{$15 \mathrm{~min}$} & \multicolumn{2}{|c|}{$30 \mathrm{~min}$} & \multicolumn{2}{|c|}{$45 \mathrm{~min}$} & \multicolumn{2}{|c|}{$60 \mathrm{~min}$} \\
\hline & & DG & $\mathrm{PA}$ & $\mathrm{DG}$ & PA & $D G$ & PA & $\mathrm{DG}$ & PA \\
\hline $16: 0$ & 12 & 12 & 15 & 12 & 12 & 11 & 15 & 12 & 12 \\
\hline $16: 1$ & $<1$ & $<1$ & 2 & 1 & $<1$ & $<1$ & $<1$ & 1 & $<1$ \\
\hline $18: 0$ & 30 & 32 & 32 & $32^{\circ}$ & 32 & 33 & 31 & 33 & 31 \\
\hline $18: 1$ & 19 & 18 & 19 & 18 & 19 & 18 & 19 & 18 & 19 \\
\hline $18: 2$ & 13 & 12 & 12 & 13 & 13 & 12 & 13 & 12 & 13 \\
\hline $18: 3 \omega 3$ & 3.4 & 3.1 & 2.9 & 3.3 & 3.3 & 4.1 & 3.3 & 2.8 & 3.5 \\
\hline $20: 3 \omega 6$ & 4.7 & 4.8 & 4.2 & 4.8 & 4.3 & 4.9 & 4.6 & 4.8 & 5.0 \\
\hline $20: 4 \omega 6$ & 5.5 & 5.4 & 3.7 & 5.3 & 4.7 & 5.3 & 5.2 & 5.3 & 5.5 \\
\hline $22: 5 \omega 6$ & 1.6 & 1.6 & 1.7 & 1.3 & 3.3 & 1.0 & 0.7 & 1.7 & 1.2 \\
\hline $22: 6 \omega 3$ & 7.5 & 7.4 & 5.8 & 7.3 & 6.3 & 7.5 & 6.7 & 7.0 & 7.2 \\
\hline $24: 4 \omega 6$ & 1.3 & 1.6 & 0.8 & 1.3 & 1.3 & 1.4 & 0.8 & 2.2 & 1.4 \\
\hline $\begin{array}{l}\text { Extent of } \\
\text { reaction }\end{array}$ & 0 & & $15 \%$ & & $\%$ & & & & \\
\hline
\end{tabular}

a $D G$, diglycerides; PA, phosphatidic acid; acid compositions, mole percent.

identical to that of the initial diglycerides. The closer the phosphorylation reaction approaches completion, the less the differences in reaction rate are likely to influence the composition of the product.

The stereospecificity of the kinase reaction is indicated in Figure 2. The rapid leveling off of the reaction mixture containing 2,3dipalmitin suggests that the reaction observed may have been due to some impurity in the reaction system.

The data obtained in analyzing the fatty acid distributions in a sample of rat liver triglyeerides are given in Table III. The table is arranged to indicate the method of calculating the distribution of acids between the three positions of the triglycerides. The per cent of total acids at each position is, of course, $33 \%$, so that palmitate at the 1-position is $19 \%$ of the total acids or $57 \%$ of those acids at that position in the triglycerides. The 1-position clearly contained most of the saturated fatty acids and thus differed markedly from the 3-position which contained principally unsaturated acids. Oleate and linoleate constituted over $70 \%$ of the acids at the 3position and over $90 \%$ of those at the 2 position.

\section{DISCUSSION}

The present method for calculating the acid composition at 1- and 3-positions involves differences between separate gas chromatographic analyses. These analyses must be determined with reasonable precision to avoid large percentage errors in the final calculated values. In addition, the conditions for the enzyme-catalyzed reactions were designed to produce monoglycerides, diglycerides and phosphatidates that would be truly representative of the acids in the corresponding positions in original triglyceride.
Pancreatic lipase eatalyzed hydrolysis of triglycerides has been shown to proceed independent of the long chain fatty aeid composition of the glycerides $(3,17)$. This generalization may not hold for glyeerides containing short-chain aeids (18), but the results in this and earlier (3) work indicate that the lipase was not influenced by the slight differences between palmitate, oleate, linoleate and stearate. Recently Bottino et al. (19) showed that certain long chain esters (20:5 and 22:6) in triglyeerides of marine origin were resistant to hydrolysis with pancreatie lipase. On the other hand, Mattson and Volpenhein (20) found that the acids of chain length greater than 18 earbons were esterified almost exclusively at the 1 - and 3 -positions in vegetable fats, and were thus cleaved with

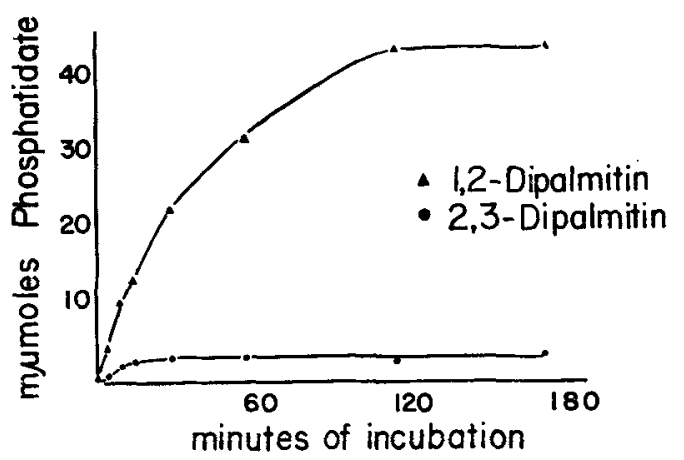

FIG. 2. Stereospecificity of diglyceride kinase. The incubation system contained $2.4 \mathrm{mM}{ }^{32} \mathrm{P}$-ATP; $93 \mathrm{mM}$ magnesium chloride; $0.93 \%(v / v)$ Cutseum (Fisher Scientific Co., Fairlawn, N.J.) ; $46.5 \mathrm{mM}$ sodium phosphate buffer, $\mathrm{pH} 7.5 ; 0.58 \mathrm{mg}$ of protein of a heat-treated particulate preparation of $E$. coli suspended in $0.05 \mathrm{ml}$ of $0.1 \%$ eysteine hydrochloride 0.01 a sodium phosphate, $\mathrm{pH} 7.0$; and either $0.47 \mathrm{mM}$ 1,2- or 2,3-dipalmitin. The reagents in a final volume of $0.215 \mathrm{mI}$ were ineubated at $37 \mathrm{C}$ for various times as indicated. 
TABLE III

Distribution of Acids Among the Three Positions of Rat Liver Triglycerides

\begin{tabular}{|c|c|c|c|c|c|c|c|c|}
\hline \multirow[b]{3}{*}{ Acid } & \multirow{2}{*}{\multicolumn{5}{|c|}{ Composition (mole percent) }} & \multicolumn{3}{|c|}{ Distribution (percent) } \\
\hline & & & & & & \multicolumn{3}{|c|}{ position } \\
\hline & $\begin{array}{l}\text { (I) } \\
\mathrm{TG}^{\mathrm{a}}\end{array}$ & $\begin{array}{l}\text { (II) } \\
\mathrm{PA}^{b}\end{array}$ & $\begin{array}{l}(\mathrm{III}) \\
\mathrm{MG} \mathrm{B}^{\mathrm{b}}\end{array}$ & $\begin{array}{c}(\text { IV }) \\
\mathrm{PA} \times 2 / 3\end{array}$ & $\frac{(\mathrm{V})}{\mathrm{M}(\times) \times 1 / 3}$ & $\begin{array}{c}1 \\
(\mathrm{IV}) \cdot(\mathrm{V})\end{array}$ & $\stackrel{2}{(\mathrm{~V})}$ & $\begin{array}{c}3 \\
\text { (I) } \cdot \text { (IV) }\end{array}$ \\
\hline $16: 0$ & $\begin{array}{c}26.2 \\
(28.6-29.6)\end{array}$ & $\begin{array}{c}30.3 \\
(26.1-37.9)\end{array}$ & $\begin{array}{c}3.7 \\
(3.0-4.0)\end{array}$ & 20.2 & 1.2 & 19 & 1.2 & 6.0 \\
\hline $16: 1$ & $\begin{array}{c}4.0 \\
(3.3-4.4)\end{array}$ & $\begin{array}{c}1.7 \\
(1.3-2.5)\end{array}$ & $\begin{array}{c}2.4 \\
(2.0-2.7)\end{array}$ & 1.2 & 0.8 & 0.4 & 0.8 & 2.8 \\
\hline $18: 0$ & $\begin{array}{c}3.1 \\
(2.8-3.6)\end{array}$ & $\begin{array}{c}4.1 \\
(2.8-6.8)\end{array}$ & $\begin{array}{c}0.7 \\
(0.5-0.8)\end{array}$ & 2.7 & 0.2 & 2.5 & 0.2 & 0.8 \\
\hline $18: 1$ & $\begin{array}{c}33.8 \\
(33.1-35.6)\end{array}$ & $\begin{array}{c}28.9 \\
(25.3-32.4)\end{array}$ & $\begin{array}{c}39.3 \\
(38.9-39.6)\end{array}$ & 19.3 & 13.1 & 6.2 & 13 & 14 \\
\hline $18: 2$ & $\begin{array}{c}32.9 \\
(31.0-34.5)\end{array}$ & $\begin{array}{c}34.9 \\
(31.4-37.4)\end{array}$ & $\begin{array}{c}53.9 \\
(52.9-55.1)\end{array}$ & 23.3 & 18.0 & 5.3 & 18 & 10 \\
\hline
\end{tabular}

a Average of 4 experiments. TG, triglyceride.

b Average of 3 experiments. PA, phosphatidic acid; MG, monoglyceride.

c Numbers in parentheses indicate range.

lipase. Several conflicting reports in the literative [e.g. Coleman (21)] make it difficult to say that all triglycerides tested will be satisfactorily analyzed by this procedure. The ease of analyzing the products and unreacted triglycerides makes it desirable to check any new triglyceride mixture during the stereospecific analysis to establish that the lipase reaction rate was independent of the component acids under the conditions used.

The observed relative distribution of oleate (Table III) between the 2- and 3-positions requires a modification of the generalization that the unsaturated fatty acids are esterified preferentially at the 2-position (22). In the past, only the average ester compositions of the primary positions could be measured and the differences between the 1- and 3-positions shown in Table III were not recognized. The recent work of Brockerhoff et al. has also shown that these two positions have different compositions in some tissues $(23,24)$. We found a greater degree of asymmetry in the triglycerides of rat liver than has been reported for adipose tissue of rats (24).

Diglycerides, which are undoubtedly the precursors of triglycerides, may be formed either from phospholipids or preexisting triglycerides. If triglyceride lipase produced both 1,2- and 2,3-diglycerides, a nonstereoselective reacylation (25) to triglycerides could lead to a randomization of the acids between the two primary esters. On the other hand, acylation of 1,2diglycerides derived from phospholipids would lead to differences in composition between the primary positions. This would oceur if the diglyceride :acyl-CoA acyltransferases had specificities different from those of the enzymes which acylate the 1-position of the various phospholipids, or if these enzymes operated on different pools of acyl-CoAs. Our analyses inLiPIDS, VoL. 1, No. 6 dicate that in rat liver, the control of the composition of the 3-position is clearly different from that at the 1-position.

\section{ACKNOWLEDGMENT}

Supported in part by grant AM 05310 from the USPHS. The triglyceride lipase was purified for us by John Champe.

\section{REFERENCES}

1. Slakey, Sr. P. M., W. E. M. Lands and R. A. Pieringer, Fed. Proc. 25, 521 (1.966).

2. Hilditch, T. P., "The Chemical Constitution of Natural Fats," John Wiley and Sons, Inc., New York, 1956.

3. Mattson, F. H., and L. Beck, J. Biol. Chem. 219, 735 (1956).

4. Tattrie, N. H., R. A. Bailey and M. Kates, Arch. Biochem. Biophys. 78, 319 (1958).

5. Vander Wal, R. J., JAOCS 37, 18 (1960).

6. Coleman, M. H., and W. C. Fulton, in "Enzymes of Lipid Metabolism," P. Desnuelle, ed., Pergamon Press, New York, 1961, p 127.

7. Vander Wal, R. J., Advan. Lipid Res. 2, 1 (1964)

8. Jurriens G., B. De Vries and L. Schouten, J. Lipid Res. $5,366(1964)$.

9. Schwartz, P., and H. E. Carter, Proc. Natl. Acad. Sei. U. S. 40,499 (1954).

10. Hirschmann, H., J. Biol. Chem. 235, 2762 (1960).

11. Brockerhoff, H., J. Lipid Res. 6, 10 (1965).

12. Lands, W. E. M., and A. Zschocke, J. Lipid Res. 6,324 (1965).

13. Mattson, F. H., R. A. Volpenhein and J. B Martin, J. Lipid Res. 5, 374 (1964).

14. Desnuelle, P., M. J. Constantin and J. Baldy, Bull. Soc. Chim. Biol. 37, 285 (1955).

15. Pieringer, R. A., and R. S. Kunnes, J. Biol. Chem 240,2833 (1965).

16. Lands, W. E. M., and P. Hart, JAOCS 43, 290 (1966).

17. Savary, P., and P. Desnuelle, Biochim. Biophys. Acta 21,349 (1956).

18. Entressangles, B., P. Savary, M. J. Constantin and P. Desnuelle, Biochim. Biophys. Acta 84, 140 (1964).

19. Bottino, N. R., G. Vanderburg and R. Reiser, Fed. Proc. 25, 301 (1966).

20. Mattson, F. H., and R, A. Volpenhein, J. BioI Chem. 236, 1891 (1961).

21. Coleman, M. A., JAOCS 40, 568 (1963).

22. Desnuelle, P., and P. Savary, J. Lipid Res. 4, 369 (1963).

23. Brockerhoff, H., and M. Yurkowski, J. Lipid Res. 7,62 (1966).

24. Brockerhoff, H., R. J. Hoyle and N. Wolemark, Biochim. Biophys. Aeta 116, 67 (1966).

25. Weiss, S. B., E. P. Kennedy and J. Y. Kiyasu, J. Biol. Chem. 235, 40 (1960).

[Received May 26, 1966] 